\title{
WZROST GOSPODARCZY A ZATRUDNIENIE W POLSCE W LATACH 1995-2014
}

\section{(Streszczenie)}

Wzrost gospodarczy jest jednym z warunków kształtujących rynek pracy. Dodatnia zależność obu tych kategorii co do zasady nie budzi wątpliwości, ale bardziej skomplikowana jest kwestia ilościowych relacji zachodzących między nimi.

W opracowaniu podjęto próbę analizy zależności między stopami wzrostu PKB i liczby pracujących w Polsce w latach 1995-2014 oraz próbę ustalenia charakteru wzrostu gospodarczego w badanym okresie. Starano się uzyskać odpowiedź na kilka pytań badawczych, tj.: Jaka była dynamika zmian PKB i liczby pracujących w latach 1995-2014? Jak kształtował się współczynnik absorbcji zatrudnienia w różnych okresach rozwoju polskiej gospodarki oraz w wybranych sekcjach gospodarki? Jaka jest granica bezzatrudnieniowego wzrostu gospodarczego w Polsce?

Z przeprowadzonych badań wynika, że rynek pracy stosunkowo późno reagował na wzrost gospodarczy, zatrudnienie wzrastało dopiero wtedy, gdy stopa wzrostu gospodarczego kształtowała się na poziomie ok. $4,5 \%$.

Słowa kluczowe: wzrost gospodarczy; bezzatrudnieniowy wzrost gospodarczy; współczynnik absorpcji siły roboczej; kryzys gospodarczy

Klasyfikacja JEL: C21, O42, O47

\section{Wprowadzenie}

Zależność zatrudnienia i bezrobocia od dynamiki wzrostu gospodarczego ${ }^{1}$ jest powszechnie uznawana i występuje zarówno w neoklasycznych modelach wzro-

* Prof. zw. dr hab., Uniwersytet Ekonomiczny, Katowice; e-mail: dorota.kotlorz@ue.katowice.pl ** Dr hab., prof. UE, Uniwersytet Ekonomiczny, Katowice; e-mail: elzbieta.sojka@ue.katowice.pl 1 Najbardziej popularnym wskaźnikiem wykorzystywanym do opisu wzrostu gospodarczego jest Produkt Krajowy Brutto. Jest on miarą wielkości produkcji wytworzonej przez czynniki 
stu gospodarczego, jak i modelach keynesowskich. W praktyce jednak ma ona różny charakter. Badania tej zależności w różnych krajach i okresach wskazują na zróżnicowaną reakcję zatrudnienia i bezrobocia na wzrost gospodarczy. Wynika z nich, że wzrost zatrudnienia ma miejsce na różnych poziomach wzrostu gospodarczego ${ }^{2}$. Doświadczenia ostatnich lat w zakresie związków bezrobocia ze wzrostem gospodarczym wskazują, że w każdej kolejnej fazie wzrostu następującej po okresie spadku liczba pracujących wzrasta później i wolniej niż odpowiednie mierniki wzrostu gospodarczego. Bezrobocie zaś zmniejsza się, ale też wolniej niż wynika to z procesów wzrostu i po każdej kolejnej fazie recesji od wyższego poziomu. Przemiany gospodarcze, jakie dokonały się w Europie w ostatnich dziesięcioleciach XX w., powodują, że bezrobocie nie ma już charakteru koniunkturalnego, lecz strukturalny, niewielki jest zatem stopień wrażliwości bezrobocia na przebieg cyklu koniunkturalnego. Fluktuacje tempa wzrostu odgrywają znacznie mniejszą rolę w kształtowaniu zatrudnienia i bezrobocia niż kiedyś. Potwierdzają to także badania dotyczące stopy bezrobocia równowagi. Wzrost gospodarczy nie jest już skutecznym sposobem zmniejszania bezrobocia.

Omawiając wpływ wzrostu gospodarczego na wielkość zatrudnienia, należy przypomnieć, że wzrost gospodarczy jest funkcją wzrostu zatrudnienia i wzrostu wydajności pracy. $Z$ tej elementarnej zależności wynika, że wzrost gospodarczy następujący wyłącznie w wyniku wzrostu produktywności nie powoduje wzrostu zatrudnienia, a także, że wzrost gospodarczy może następować przy różnych tempach wzrostu zatrudnienia. Wzrost zatrudnienia zależy głównie od intensywności zatrudnieniowej wzrostu gospodarczego mierzonej wskaźnikiem udziału przyrostu zatrudnienia w przyroście $\mathrm{PKB}^{3}$. W związku z tym wyróżnia się dwa modele wzrostu gospodarczego: bezzatrudnieniowy i prozatrudnieniowy ${ }^{4}$.

We współczesnych gospodarkach występują procesy bezzatrudnieniowego wzrostu gospodarczego. Rozwój nowych technologii, postępu technicznego, rozprzestrzenianie się technik informacyjno-komunikacyjnych przyczyniają się do podnoszenia wydajności pracy i zmniejszania chłonności zatrudnieniowej

wytwórcze zlokalizowane na terytorium danego kraju, w określonym przedziale czasu, niezależnie od tego, kto jest ich właścicielem. Por. D. Begg, S. Fischer, R. Dornbusch, Ekonomia, t. 2, PWE, Warszawa 1994, s. 22.

2 E. Kwiatkowski, S. Roszkowska, T. Tokarski, Granice wzrostu bezzatrudnieniowego w Europie i krajach WNP, Ekonomista 2004/1, s. 39.

3 E. Kryńska (red.), Rynek pracy w wybranych krajach. Metody przeciwdziałania bezrobociu, IPiSS, Warszawa 1999, s. 26.

4 E. Kwiatkowski, S. Roszkowska, E. Tokarski, op. cit., s. 39. 
wzrostu gospodarczego. Może to prowadzić do bezzatrudnieniowego wzrostu gospodarczego, a zatem wzrostu gospodarczego bez zwiększenia zatrudnienia ${ }^{5}$.

Przedmiotem podjętej w opracowaniu analizy są relacje między stopami wzrostu PKB i liczby pracujących w całej gospodarce narodowej oraz zróżnicowanie tych relacji w wybranych sekcjach gospodarki polskiej w latach 1995-2014.

W opracowaniu podjęto próbę odpowiedzi na następujące pytania badawcze:

1. Jaka była dynamika zmian PKB oraz liczby pracujących w latach 1995-2014?

2. Jak kształtował się współczynnik absorbcji zatrudnienia w różnych okresach rozwoju polskiej gospodarki? Tym samym starano się zbadać, jaka jest reakcja zatrudnienia (liczby pracujących) na wzrost gospodarczy w różnych okresach.

3. W której z wybranych do analizy sekcji gospodarki współczynnik absorpcji zatrudnienia był najwyższy, a w której najniższy?

4. Jaka jest granica bezzatrudnieniowego wzrostu gospodarczego w Polsce? W tym celu wykorzystano model będący funkcją popytu na pracę opartą na keynesistowskich modelach wzrostu gospodarczego typu Harroda-Domara.

W przypadku analiz prowadzonych dla całej gospodarki badania objęy lata 1995-2014, natomiast w analizach dotyczących wybranych sekcji gospodarki, ze względu na dostępność odpowiednich danych statystycznych, okres badania był krótszy i objął dwanaście lat, tj. 2003-2014.

Opracowanie ma charakter analizy ilościowej, a odpowiednie dane statystyczne pozyskano z bazy danych GUS oraz Roczników Statystycznych Województw za lata 2006-2015.

\section{Dynamika zmian PKB a zmiany w zatrudnieniu}

Na wykresie 1 przedstawiono dynamikę zmian PKB (ceny stałe) oraz liczby pracujących w gospodarce narodowej $(1995=100)$, natomiast wykres 2 przedstawia zmiany wielkości makroekonomicznych w stosunku do roku poprzedniego.

W porównaniu do $1995 \mathrm{r}$. PKB (w cenach stałych) wzrósł ponad dwukrotnie, natomiast liczba pracujących wykazywała tendencję spadkową. W 2014 r. wystapił spadek zatrudnienia o 6\% w stosunku do okresu bazowego.

Zob. M. Timmer et al., Economic Growth in Europe. A Comparative Industry Perspective, Cambridge 2010; K. Aiginger, Labour market reforms and economic growth - the European experience in the nineties, WIFO Working Papers 2004/232; R.J. Barro, X. Sala-i-Martin, Economic Growth, MIT Press, Cambridge 2004. 
WYKRES 1: Dynamika zmian PKB (ceny state) i liczby pracujacych $w$ Polsce $w$ latach 1995-2014 $(1995=100)$

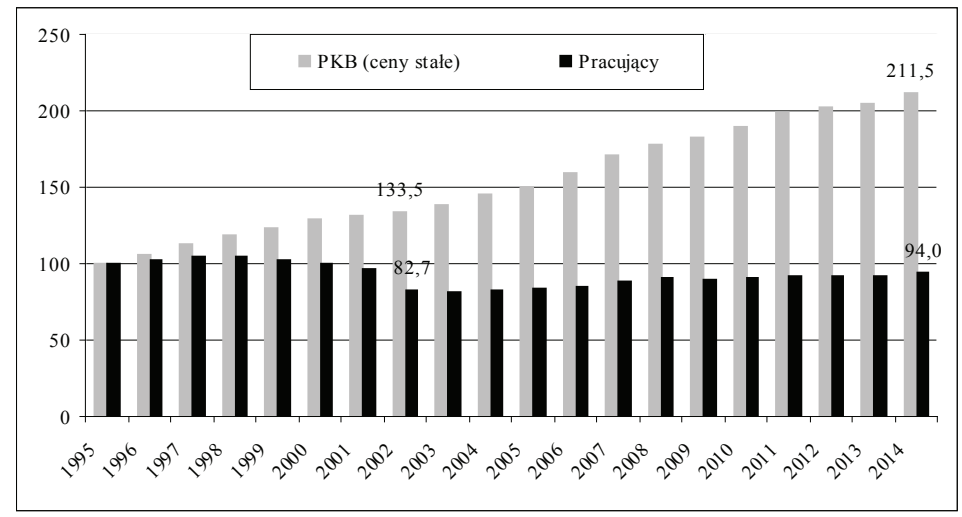

Ź ró dło: opracowanie własne na podstawie bazy danych GUS oraz Rocznika Statystycznego Województw za lata 2006-2015.

Biorąc pod uwagę tempo zmian obu analizowanych zjawisk (wykres 2), można zauważyć, że w całym okresie przyjętym do badania było ono zawsze wyższe w przypadku PKB niż liczby pracujących.

WYKRES 2: Dynamika zmian PKB (ceny state) i liczby pracujacych w Polsce w latach 1995-2014 (rok poprzedni $=100$ )

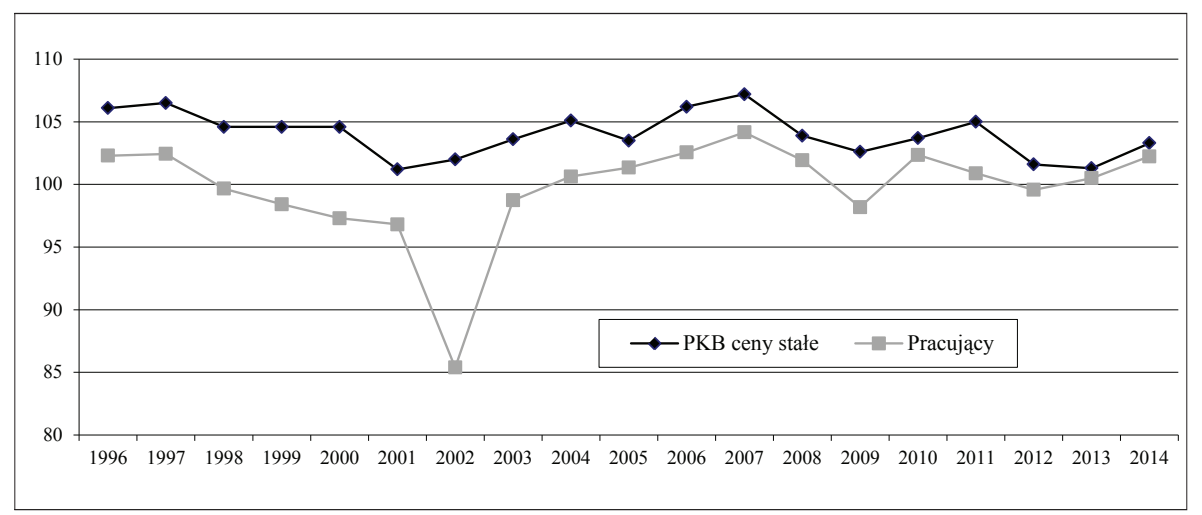

Ź ró d ł o: opracowanie własne na podstawie danych GUS oraz Rocznika Statystycznego Województw za lata 2006-2015. 
W latach 1995-2014 polska gospodarka rozwijała się według różnych scenariuszy czy strategii. Cały badany okres można podzielić na cztery podokresy (tabela 1, wykresy 2 i 3). Pierwszy obejmował lata 1995-1997 i cechował się wysokim średnim tempem wzrostu PKB (6,3\% średniorocznie), relatywnie wysokim tempem wzrostu liczby pracujących (2,4\% średniorocznie) i spadkiem bezrobocia rejestrowanego o 16,6\% średniorocznie (z 2629 tys. w 1995 r. do 1826 tys. w 1997 r.). Obserwowane jednak w tym okresie dodatnie wzrosty liczby pracujących są znacznie niższe od stóp wzrostu PKB. Wskazuje to na bezzatrudnieniowy charakter wzrostu gospodarczego. Sytuacja ta była wynikiem wielu czynników, ale przede wszystkim wzrostu wydajności pracy ${ }^{6}$, zmian strukturalnych w gospodarce, a także efektu konwergencji.

TABELA 1: Wzrost PKB i liczby pracujacych w Polsce w latach 1995-2014

\begin{tabular}{|c|c|c|c|c|}
\hline \multirow{2}{*}{ Okresy } & \multicolumn{3}{|c|}{ Średnie roczne tempo wzrostu (\%) } & Współczynnik \\
\cline { 2 - 4 } & PKB (ceny stałe) & pracujących & bezrobotnych* & zatrudnienia \\
\hline $1995-1997$ & 6,3 & 2,4 & $-16,6$ & 0,38 \\
\hline $1998-2002$ & 3,1 & $-5,7$ & 15,1 & $-1,84$ \\
\hline $2003-2008$ & 5,2 & 2,1 & $-14,2$ & 0,40 \\
\hline $2009-2014$ & 3,0 & 1,1 & $-0,7$ & 0,37 \\
\hline $1995-2014$ & 4,0 & $-0,3$ & $-1,9$ & $-0,08$ \\
\hline $2003-2014$ & 3,9 & 1,0 & $-4,9$ & 0,24 \\
\hline
\end{tabular}

* bezrobotni zarejestrowani.

Źr ó dło: obliczenia własne na podstawie danych GUS.

Drugi okres (1998-2002) cechuje o połowę niższe średnie tempo wzrostu gospodarczego, spadek liczby pracujących oraz wzrost bezrobocia o $15,1 \%$ średniorocznie. Te negatywne zjawiska były w dużym stopniu skutkiem rozpoczętego w 1997 r. „schładzania” gospodarki. Nacisk położono na równowagę finansową i realizację celu inflacyjnego, a nie na wzrost gospodarczy. Realizując cel inflacyjny ${ }^{7}$, utrzymywano bardzo wysokie nominalne i realne stopy procentowe.

6 Zob. D. Kotlorz, Przeobrażenia struktur zatrudnienia w Polsce w okresie transformacji - wybrane problemy, GWSH Katowice 2004, s. 48. Porównując indeksy wydajności pracy i zatrudnienia, widać, że do wzrostu PKB w 2001 r. w stosunku do 1995 r. przyczynił się głównie wzrost wydajności pracy. Dotyczy to także okresów wcześniejszych: 1995 r. w stosunku do roku1990, zob. D. Kotlorz, Zatrudnienie w procesie przemian polskiej gospodarki, AE, Katowice 1999, s. 62.

7 Ibidem, s. 79 i n. 
Miało to wpływ na wysokość realnego oprocentowania kredytów na cele gospodarcze, a tym samym na poziom i dynamikę popytu inwestycyjnego i wydatków konsumpcyjnych w postaci efektów thumienia wzrostu gospodarczego. Również sposób redukcji powiększającego się deficytu budżetowego, a szerzej finansów publicznych wywarł negatywny wpływ na wzrost gospodarczy i zatrudnienie. Realizowana w Polsce w latach 1999-2000 polityka stabilizacyjna charakteryzowała się nadmiernie restrykcyjną polityką pieniężną i zbyt łagodną polityką fiskalną. Była to niekorzystna z punktu widzenia wzrostu gospodarczego i zatrudnienia kombinacja polityki makroekonomicznej. Na spadek zatrudnienia wpłynęła też polityka aprecjacji złotego, zmniejszając konkurencyjność krajowych producentów i czyniąc import bardziej opłacalnym. Na obniżenie stopy wzrostu PKB wpłynęło też obniżenie dynamiki eksportu związane z kryzysem rosyjskim i obniżenie stóp wzrostu PKB w gospodarce niemieckiej ${ }^{8}$, a także gwałtowny (w latach 1999-2000) wzrost ceny ropy naftowej na światowych rynkach. Skutkiem tego był obserwowany od 1999 r. spadek liczby pracujących w gospodarce polskiej i wzrost stopy bezrobocia. Należy jednak zwrócić uwagę, że dopiero od 2001 r. miał miejsce wyraźny spadek tempa wzrostu, czyli spadek zatrudnienia rozpoczął się z jeszcze większym wyprzedzeniem w stosunku do spowolnienia gospodarki. Na wzrost bezrobocia wpływ miały niewatpliwie takie czynniki, jak szybki przyrost liczby osób w wieku produkcyjnym i dążenie przedsiębiorców do obniżenia kosztów osobowych poprzez redukcję zatrudnienia. Wyniki badań dotyczących stopy bezrobocia równowagi ${ }^{9}$ wskazuja, że wpływ fluktuacji tempa wzrostu gospodarczego na poziom bezrobocia jest we współczesnych gospodarkach (ze względu na przemiany gospodarcze) znacznie niższy niż kilkadziesiąt lat temu. Na poziom bezrobocia coraz większy wpływ mają obecnie czynniki strukturalne ${ }^{10}$.

W trzecim okresie (2003-2008) obserwowano ponad 5\% wzrost gospodarczy, ponad 2\% wzrost liczby pracujących oraz spadek bezrobocia. Czynnikiem dynamizującym rozwój gospodarczy tego okresu była akcesja Polski do Unii Europejskiej. Aktywność gospodarcza osiagnęła maksimum w 2007 r. (wzrost PKB w skali roku wyniósł 6,8\%) ${ }^{11}$. W latach 2004-2008 (z wyjątkiem 2005 r.) o tempie wzrostu gospodarczego decydowała wysoka dynamika popytu krajo-

8 E. Kwiatkowski, L. Kucharski, T. Tokarski, Bezrobocie i zatrudnienie a PKB w Polsce w latach 1993-2001, Ekonomista 2002/3, s. 330.

9 M. Góra, Trwale wysokie bezrobocie w Polsce - wyjaśnienia i propozycji, Ekonomista 2005/1, s. 32.

10 Ibidem.

11 Polska 2010 - raport o stanie gospodarki 2010, Warszawa 2010, s. 75 i 88. 
wego. Utrzymujące się w tym okresie tendencje wzrostowe (PKB i zatrudnienia) w 2009 r. znacznie spowolniały na skutek globalnego kryzysu ekonomicznego 2008/2009. W ostatnim czwartym okresie (2009-2014) średnioroczne tempo wzrostu PKB nieco osłabło i wyniosło $3 \%{ }^{12}$, przy relatywnie niższym wzroście liczby pracujących w stosunku do poprzedniego okresu. W latach 2008/2009 globalny kryzys ekonomiczny skutkował w Polsce obniżeniem wzrostu PKB, wyniósł on w 2009 r. 1,8\% i był najniższy od czasów kryzysu rosyjskiego, dopiero w ostatnim kwartale tego roku wzrost przyspieszył do 3\%. W 2009 r. popyt krajowy przestał być głównym czynnikiem wzrostu gospodarczego i jego wkład w PKB był ujemny. Sytuacja ta była głównie wynikiem obniżenia tempa wzrostu realnych wynagrodzeń gospodarstw domowych i gorszej sytuacji finansowej przedsiębiorstw. Rolę stymulatora gospodarki przejął popyt zewnętrzny, którego wkład w 2009 r. był dodatni. W 2009 r. nastąpił spadek zarówno eksportu, jak i importu. W latach 2010-2011 nastapiło przyspieszenie wzrostu gospodarczego, czynnikiem decydującym o wzroście PKB był popyt krajowy. Ta korzystna sytuacja trwała tylko przez dwa lata, w następnych dwóch tempo wzrostu gospodarczego spowolniało. Było to spowodowane w znacznym stopniu negatywnym wpływem na gospodarkę drugiej fali światowego kryzysu gospodarczego. Czynnikiem decydującym o wzroście PKB był eksport netto. W połowie $2013 \mathrm{r}$. nastapiły symptomy ożywienia kontynuowane także w 2014 r.

Od strony „ilościowej” oba spowolnienia wzrostu gospodarczego obserwowane w latach 1998-2002 oraz 2009-2014 cechuje pewne podobieństwo. W czasie pierwszego średnioroczna dynamika PKB obniżyła się z 6,3\% do 3,1\%, natomiast w czasie drugiego (2009-2014) spadła z 5,2\% do 3\%. Zatem redukcja tempa wzrostu gospodarczego była większa w pierwszym okresie, tj. 1998-2002, ale zupełnie inna była reakcja liczby pracujących na to spowolnienie wzrostu.

Na wykresie 3 przedstawiono zmiany średniego tempa wzrostu wybranych wielkości makroekonomicznych w dwóch okresach, tj. 1995-2014 oraz 2003-2014, dla których - w dalszej części opracowania - zostaną wyznaczone modele ekonometryczne pozwalające analizować zjawisko bezzatrudnieniowego wzrostu gospodarczego.

12 Ibidem. 
WYKRES 3: Średnie roczne tempo wzrostu wielości makroekonomicznych w Polsce w okresach: 1995-2014 i 2003-2014 (w\%)

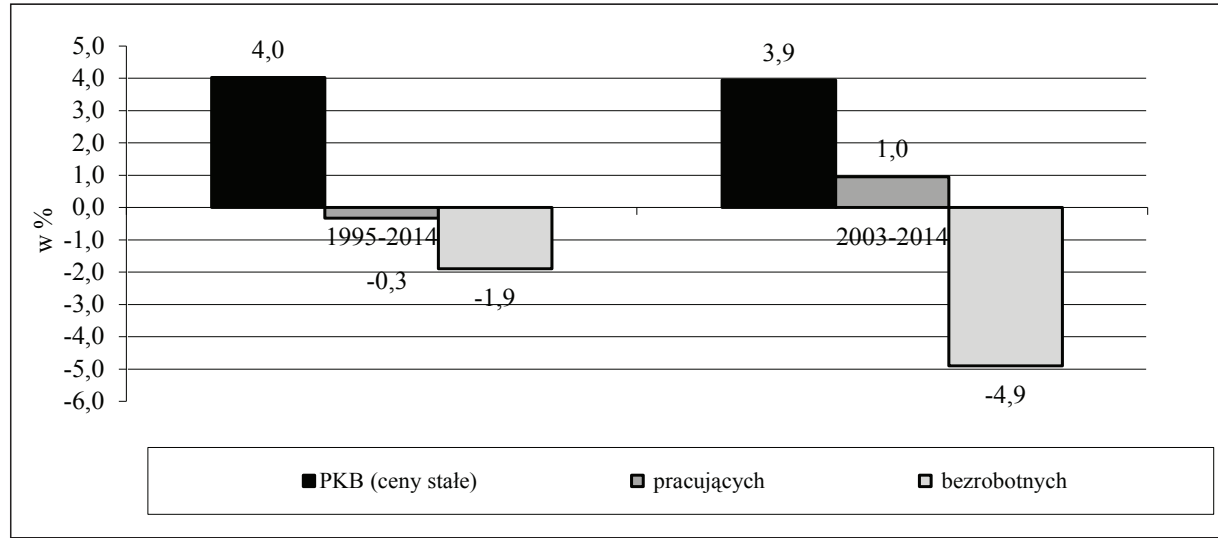

Źr ó d ło: opracowanie własne na podstawie danych GUS.

O ile w obu okresach średnioroczne tempo wzrostu PKB było na podobnym poziomie (ok. 4\%), to w latach 2003-2014 zatrudnienie rosło średnio z roku na rok o ok. $1 \%$, a spadek liczby bezrobotnych wynosił $4,9 \%$ średniorocznie.

Chcąc uzyskać odpowiedź na drugie i trzecie pytanie badawcze postawione we wstępie pracy, w tabeli 1 i 2 przedstawiono zmiany współczynnika absorbcji pracujących przez wzrost gospodarczy. Współczynnik ten obliczany jest jako iloraz procentowego przyrostu zatrudnienia i procentowego przyrostu PKB. Informuje on, o ile procent zmieni się zatrudnienie, jeśli dynamika PKB zmieni się o 1\%.

W latach 1998-2002 stopień absorpcji wynosił-1,84, podczas gdy w okresie 2009-2014 był na poziomie 0,37. Oznacza to, że w pierwszym okresie spowolnienia gospodarczego wzrostowi PKB o $1 \%$ towarzyszył spadek zatrudnienia o $1,84 \%$, natomiast w drugim - wzrost o $0,37 \%$. Powyższa analiza prowadzi do wniosku, że spowolnienie gospodarcze obserwowane w latach 1998-2002 oraz 2009-2014 wywoływało spadek popytu na pracę, ale skala tego spadku była zróżnicowana oraz znacznie większa w pierwszym okresie niż w drugim. W okresach przyspieszonego wzrostu gospodarczego rośnie popyt na pracę, co sprzyja ograniczaniu bezrobocia.

Badanie zależności między tempem wzrostu gospodarczego (tempem wzrostu wartości dodanej brutto) a tempem wzrostu zatrudnienia (liczby pracujących) przeprowadzono również dla wybranych sekcji gospodarki narodowej (tabela 2). Ze względu na dostępność danych analiza objęła okres dwunastu lat, tj. 2003-2014. 
TABELA 2: Wzrost wartości dodanej brutto (ceny state) i liczby pracujących w wybranych sekcjach gospodarki narodowej w okresie 2003-2014

\begin{tabular}{|c|l|c|c|c|}
\hline \multirow{2}{*}{ Lp. } & \multicolumn{1}{|c|}{ Sekcja } & \multicolumn{2}{|c|}{ Średnie roczne tempo wzrostu (w \%) } & Współczynnik \\
\cline { 3 - 4 } & & wartość dodana brutto & pracujący & $\begin{array}{c}\text { absorbji } \\
\text { zatrudnienia }\end{array}$ \\
\hline 1 & $\begin{array}{l}\text { Rolnictwo, leśnictwo, } \\
\text { łowiectwo i rybactwo }\end{array}$ & 0,9 & 1 & 1,11 \\
\hline 2 & Górnictwo i wydobywanie & $-3,3$ & -2 & 0,61 \\
\hline 3 & Przetwórstwo przemysłowe & 7,4 & $-5,1$ & 0,04 \\
\hline 4 & $\begin{array}{l}\text { Wytwarzanie i zaopatrywanie } \\
\text { w energię elektryczna, gaz, } \\
\text { parę wodną i gorącą wodę }\end{array}$ & 2,9 & 2,6 & 0,59 \\
\hline 5 & Budownictwo & 4,4 & 0,8 & 0,27 \\
\hline 6 & Handel i naprawy & 3,0 & 0,5 & 0,12 \\
\hline 7 & $\begin{array}{l}\text { Transport, gospodarka } \\
\text { magazynowa i łączność }\end{array}$ & 4,2 & & 0,3 \\
\hline
\end{tabular}

Ź r ó dło: obliczenia własne na podstawie danych GUS, Polska - wskaźniki makroekonomiczne http://stat.gov.pl/wskazniki-makroekonomiczne/

$\mathrm{Z}$ analizy danych zawartych w powyższej tabeli można sformułować następujące spostrzeżenia:

a) największe średnioroczne tempo wzrostu wartości dodanej brutto - na przestrzeni badanego okresu - obserwowano w sekcji: przetwórstwo przemysłowe (o 7,4\%), natomiast najniższe (o $0,9 \%$ ) w rolnictwie, leśnictwie, łowiectwie i rybactwie;

b) wartość dodana brutto spadała, średnio z roku na rok o 3,3\% w sekcji: górnictwo i wydobywanie. W tym samym czasie tempo spadku zatrudnienia było na poziomie $2 \%$ średniorocznie;

c) w budownictwie, przy dosyć znacznym tempie wzrostu wartości dodanej brutto, dał się zaobserwować znaczy wzrost zatrudnienia, tj. o 2,6\% średniorocznie. W sekcji 4 widoczna jest zależność przeciwna tzn. wzrost wartości dodanej brutto o $2,9 \%$ przy spadku zatrudnienia o 5,1\% średnio z roku na rok;

d) współczynnik absorbcji zatrudnienia był najwyższy w rolnictwie i leśnictwie (sekcja 1), a najniższy w przetwórstwie przemysłowym (sekcja 3). Wartości tych współczynników informują że wzrostowi wartości dodanej o 1\% towarzyszył wzrost zatrudnienia odpowiednio o: $1,11 \%$ oraz $0,04 \%$;

e) w sekcji 4 współczynnik absorpcji przyjmuje wartość ujemną, co oznacza, że wzrostowi wartości dodanej brutto towarzyszył spadek zatrudnienia o 1,76\%. 


\section{Funkcja popytu na pracę - metoda i wyniki badania}

Zależność między tempem wzrostu gospodarczego a tempem wzrostu liczby pracujących może być też analizowana z wykorzystaniem keynesistowskiego modelu wzrostu gospodarczego typu Harroda-Dommara, zgodnie z którym popyt na pracę jest rosnącą funkcją produkcji (PKB) i malejącą funkcją wydajności pracy. Innymi słowy, popyt na pracę rośnie, jeśli produkcja rośnie szybciej od wydajności pracy. W tego typu analizach prezentowany poniżej model wzrostu gospodarczego jest najczęściej wykorzystywany w praktyce (Kwiatkowski, Rogut, Tokarski, 2004; Jadamus-Hacura, Melich, 2004; Jarmołowicz, Kuźmar, 2016).

Punktem wyjścia było następujące równanie popytu na pracę:

$$
\ln \left(L P_{t}\right)=\gamma+\alpha t+\ln \left(Y_{t}\right)
$$

gdzie:

$L P_{\mathrm{t}}-$ liczba pracujących $\mathrm{w}$ gospodarce $\mathrm{w}$ roku $t$,

$Y_{t}-\mathrm{PKB}$ w roku $t$,

$T$ - zmienna czasowa,

$\gamma \quad-$ wyraz wolny,

$\alpha$ - średniookresowe tempo wzrostu lub spadku liczby pracujących, będące wynikiem oddziaływania innych czynników determinujących zmiany liczby pracujących niż PKB (np. neutralny postęp techniczny itp.), $\beta$ - elastyczność popytu na pracę względem realnego PKB.

Obliczając dalej pierwsze różnice równania (1), uzyskuje się wyrażenie dane wzorem (2):

$$
\Delta \ln \left(L P_{t}\right)=\alpha+\beta \Delta \ln \left(Y_{t}\right)
$$

gdzie: $\quad \Delta \ln \left(L P_{t}\right) \approx \frac{\Delta L P_{t}}{L P_{t-1}} \equiv S_{L P_{t}} \quad \Delta \ln \left(Y_{t}\right) \approx \frac{\Delta Y_{t}}{Y_{t-1}} \equiv S_{Y_{t}}$

to odpowiednio stopy wzrostu liczby pracujących oraz PKB. 
Oba równania (1) i (2) pozwoliły na sformułowanie modelu pozwalającego analizować zjawisko bezzatrudnieniowego wzrostu gospodarczego:

$$
S_{L P_{t}}=\alpha+\beta S_{Y_{t}}+\xi_{t}
$$

gdzie:

$\mathrm{S}_{L P t}, \mathrm{~S}_{Y t}$ - stopa wzrostu liczby pracujących i PKB w roku t,

$\alpha \quad-$ hipotetyczne tempo zmian liczby pracujących przy zerowym wzroście PKB,

$\beta$ - elastyczność liczby pracujących względem PKB,

$\xi \quad$ - składnik losowy modelu.

Tempo wzrostu gospodarczego niepowodującego wzrostu liczby zatrudnionych oblicza się zgodnie ze wzorem:

$$
S_{Y 0}=-\frac{a}{b}
$$

gdzie:

$a$ i $b$ to oceny parametrów $\alpha$ i $\beta$ uzyskane za pomocą metody najmniejszych kwadratów.

Wielkość daną wzorem (4) można traktować jako granicę wzrostu bezzatrudnieniowego. Jeżeli tempo wzrostu gospodarczego jest mniejsze od $(-a / b)$, to liczba zatrudnionych maleje, a spadek bezrobocia i wzrost zatrudnienia są możliwe dopiero przy dalszym przyspieszeniu gospodarki.

W niniejszym opracowaniu wyznaczono granicę bezzatrudnieniowego wzrostu gospodarczego dla całej gospodarki polskiej, jak również dla wybranych siedmiu sekcji gospodarki narodowej. W przypadku całej gospodarki oszacowano dwa modele zadane równaniem (3) w oparciu o dane roczne z okresów: 1995-2014 $(\mathrm{N}=20)$ oraz 2003-2014 $(\mathrm{N}=12)$, natomiast w przypadku poszczególnych sekcji - ze względu na dostępność i kompletność danych - model (3) szacowano na podstawie krótszego, dwunastoletniego okresu.

Zależność między stopami wzrostu PKB (ceny stałe) a stopami wzrostu liczby pracujących w latach 1995-2014 oraz 2003-2014 przedstawiono na wykresie 4. 
WYKRES 4: Zależność PKB i liczby pracujących w Polsce w latach 1995-2014 (górny) i 2003-2014 (dolny)

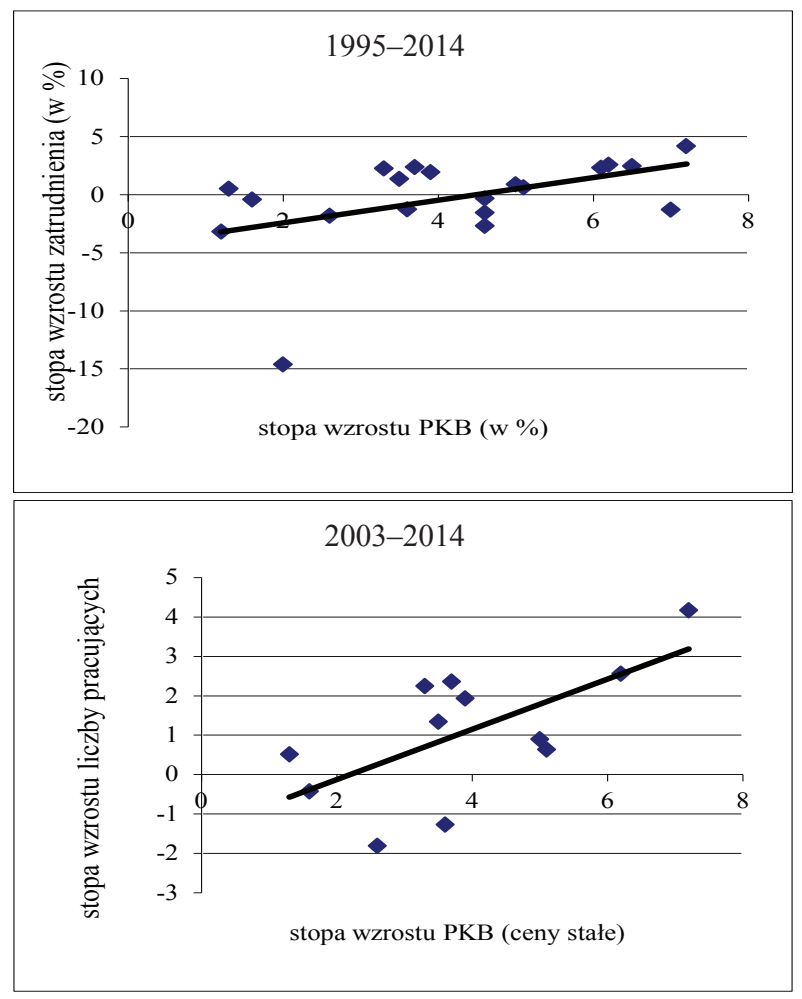

Źr ó d ł o: opracowanie własne na podstawie danych GUS i Rocznika Statystycznego Województw za lata 2006-2015.

Z powyższego rysunku wynika, że istnieje dodatnia zależność pomiędzy stopami wzrostu analizowanych zmiennych makroekonomicznych, dodatnie stopy wzrostu liczby pracujących na ogół występują przy dodatnich stopach wzrostu PKB i są one niższe od stóp wzrostu PKB (por. także wykres 1). Warto dodać, że zależność ta jest silniejsza w sensie miary korelacji $(r=0,65)$ w przypadku danych z okresu 2003-2014. Wyniki oszacowania modeli w oparciu o dane z dwóch okresów przedstawiono w tabeli 3 . 
TABELA 3: Wyniki oszacowania modeli dla gospodarki Polski w latach 1995-2014 i 2003-2014

\begin{tabular}{|c|c|c|c|c|c|c|}
\hline Okres & \multicolumn{2}{|c|}{ Oceny parametrów } & $\begin{array}{c}\text { Błąd } \\
\text { standardowy }\end{array}$ & $t$-Studenta & Wartość $p$ & $\begin{array}{c}\text { Wskaźnik } \\
(-a / b)\end{array}$ \\
\hline \multirow{2}{*}{ 1995-2014 } & $b$ & 0,975 & 0,442 & 2,206 & 0,041 & \multirow{2}{*}{4,48} \\
\cline { 2 - 6 } & $a$ & $-4,368$ & 2,013 & $-2,170$ & 0,044 & \\
\hline \multirow{2}{*}{ 2003-2014 } & $b$ & 0,638 & 0,237 & 2,692 & 0,023 & \multirow{2}{*}{2,20} \\
\cline { 2 - 6 } & $a$ & $-1,406$ & 1,01 & $-1,392$ & 0,194 & \\
\hline
\end{tabular}

Ź ró dło: obliczenia własne.

W latach 1995-2014 tempo wzrostu gospodarczego na poziomie 4,5\% gwarantowało poprawę sytuacji na rynku pracy w Polsce. Inaczej rzecz ujmując, dopiero ok. 4,5\% wzrost gospodarczy sprzyja wzrostowi zatrudnienia ${ }^{13}$. Ale już bardziej korzystna sytuacja wystąiła w przypadku obliczania wskaźnika (4) w oparciu o parametry a i $b$ modelu szacowanego na podstawie danych rocznych z okresu 2003-2014. Granica wzrostu bezzatrudnieniowego była o połowę niższa tzn. liczba pracujących w gospodarce zaczyna wzrastać już wtedy, gdy tempo wzrostu PKB przekroczy 2,2\% (wtedy tempo wzrostu liczby pracujących jest dodatnie $)^{14}$. Przyczyną takiego stanu rzeczy mogło być przystapienie w 2004 r. Polski do Wspólnoty Europejskiej i intensywny proces upodobniania się (,pościgu”) polskiej gospodarki do gospodarek starszych członków Unii. Natomiast wartość parametru $a$ modelu informuje, że przy zerowym hipotetycznie tempie wzrostu gospodarczego liczba pracujących spada o ok. 4,4\% (lata 1995-2014) i o 1,4\% w przypadku szacunków dokonanych na podstawie danych z lat 2003-2014. Warto dodać, że parametry stojące przy zmiennej objaśniającej $\left(\mathrm{S}_{\mathrm{Yt}}\right)$ w modelu (3) są statystycznie istotne $\mathrm{w}$ sensie statystyki $t$-Studenta na poziomie istotności 0,05 . Jednakże lepsze dopasowanie modelu do danych rzeczywistych otrzymano w przypadku modelu oszacowanego na podstawie dwunastu lat $\left(R^{2}=0,42\right)$.

13 Podobny wynik uzyskały M. Jadamus-Hacura i K. Melich-Iwanek. (Bezzatrudnieniowy wzrost gospodarczy - przykład Polski. Por. http://www.ue.katowice.pl/fileadmin/_migrated/ content_uploads/08_Jadamus-Hacura_Melich-Iwanek_Bezzatrudnieniowy_wzrost.pdf; stan na 11.04.2016 r., s. $\overline{83}$ ). Autorki swoje badania oparły na próbie za okres 1997-2011. Z kolei z analiz przeprowadzonych przez firmę doradztwa HR Sedlak \& Sedlak wynika, że poziom wzrostu gospodarczego, poniżej którego zatrudnienie maleje, wynosi blisko 3,7\%. Por. http:// praca.interia.pl/news-wzrost-gospodarczy-a-rynek-pracy,nId,724048; stan na 11.04.2016 r.

14 Przy zaobserwowanym w okresie próby, tj. 2003-2014, średnim tempie wzrostu PKB na poziomie 3,9\%, liczba pracujących w gospodarce zwiększała się średniorocznie o 1\% (por. tabela 1). Natomiast tempo wzrostu PKB, przy którym następuje wzrost zatrudnienia - jak wynika z modelu - wyniosło $2,2 \%$. 
W dalszym etapie badania oszacowano modele dla tych samych sekcji gospodarki, które wybrano do analizy współczynnika absorbcji zatrudnienia. Modele, w których zmienną objaśnianą była stopa wzrostu liczby pracujących w poszczególnych sekcjach, a zmienną objaśniająca - stopa wzrostu wartości dodanej brutto, oszacowano w oparciu o dane roczne za lata 2003-2014. Jednakże tylko w przypadku dwóch sekcji, tj. przetwórstwo przemysłowe i budownictwo parametr $b$ stojący przy zmiennej objaśniającej był statystycznie istotny, a wskaźniki tempa wzrostu gospodarczego niepowodującego wzrostu liczby pracujących dla tych sektorów były odpowiednio równe: $7,05 \%$ oraz 1,24\% (tabela 4).

TABELA 4: Wyniki oszacowania modeli dla wybranych sekcji gospodarki na podstawie danych za okres 2003-2014

\begin{tabular}{|l|c|c|c|c|c|c|}
\hline \multicolumn{1}{|c|}{ Okres } & \multicolumn{2}{|c|}{$\begin{array}{c}\text { Oceny } \\
\text { parametrów }\end{array}$} & $\begin{array}{c}\text { Błąd } \\
\text { standardowy }\end{array}$ & $t$-Studenta & Wartość $p$ & $\begin{array}{c}\text { Wskaźnik } \\
(-a / b)\end{array}$ \\
\hline \multirow{2}{*}{$\begin{array}{l}\text { Przetwórstwo } \\
\text { Przemysłowe }\end{array}$} & $b$ & 0,505 & 0,179 & 2,818 & 0,018 & \multirow{2}{*}{7,05} \\
\cline { 2 - 6 } & $a$ & $-3,561$ & 1,698 & $-2,097$ & 0,052 & \\
\hline \multirow{2}{*}{ Budownictwo } & $b$ & 0,747 & 0,249 & 3,000 & 0,013 & \multirow{2}{*}{1,24} \\
\cline { 2 - 6 } & $a$ & $-0,927$ & 1,786 & $-0,519$ & 0,615 & \\
\hline
\end{tabular}

Ź r ó d ł o: obliczenia własne na podstawie danych GUS, Polska - wskaźniki makroekonomiczne, http://stat.gov.pl/wskazniki-makroekonomiczne/

Wysoka wartość wskaźnika $\mathrm{S}_{\mathrm{Y} 0}$ w przetwórstwie przemysłowym niewątpliwie ma związek z postępem technicznym i wzrostem wydajności pracy. W budownictwie natomiast podwyższenia stopy wzrostu zatrudnienia należało się spodziewać już przy stopie wzrostu wartości dodanej w tej sekcji wynoszącej nieco ponad $1,2 \%$. Jest to wartość zdecydowanie niższa niż w całej gospodarce. Współczynnik determinacji w tych modelach kształtował się na poziomie 0,44 i 0,47.

Dla pozostałych sekcji badanie nie przyniosło zadowalających wyników. Żaden z oszacowanych parametrów stojących przy zmiennej objaśniającej w modelach dla tych sekcji nie okazał się istotnie różny od zera. Stąd też ze względu na nieistotne parametry pozostałych modeli wyznaczanie granicy bezzatrudnieniowego wzrostu gospodarczego na ich podstawie nie miało sensu. Ponadto modele te charakteryzowały się relatywnie niskim stopniem dopasowania do danych rzeczywistych. Nie można jednak na tej podstawie sądzić, iż związek między stopą wzrostu PKB a stopą wzrostu zatrudnienia nie zachodzi, a jedynie, że nie ma on postaci liniowej. W takich sytuacjach należałoby w modelu liniowym uwzględnić dodatkową zmienną, np. stopę inwestycji, albo szukać odpowiedniej postaci modelu nieliniowego. 


\section{Zakończenie}

Z wyników przeprowadzonej analizy wynika, że w latach 1995-2014 intensywność zatrudnieniowa wzrostu gospodarczego w Polsce była ujemna, a współczynnik absorpcji zatrudnienia wynosił $(-0,08)$. Współczynnik ten kształtował się na różnym poziomie, w różnych latach badanego okresu. Największą wartość ujemną $(-1,84)$ osiagnął w latach 1998-2002. W następnych okresach aż do 2014 r. współczynnik ten przyjmował wartości dodatnie, ale bardzo niskie. Najwyższą dodatnią wartość $(0,40)$ zaobserwowano w latach 2003-2008. Wyniki analizy wskazują na utrzymywanie się w Polsce od wielu lat bezzatrudnieniowego wzrostu gospodarczego. Można powiedzieć, że jest on cechą charakterystyczną polskiej gospodarki.

$\mathrm{Z}$ oszacowań prostego keynesowskiego modelu popytu na pracę wynika, że poziom wzrostu gospodarczego w Polsce, poniżej którego zatrudnienie maleje, wyniósł prawie $4,5 \% \mathrm{w}$ przypadku szacunków prowadzonych na podstawie danych za okres 1995-2014 i był o połowę niższy (2,2\%), gdy obliczenia przeprowadzono na próbie za okres 2003-2014, przy średniorocznym tempie wzrostu PKB na zbliżonym poziomie ok. 4\% w obu badanych okresach. Oznacza to, że po wejściu Polski w struktury UE nastapiło istotne obniżenie bezzatrudnieniowego tempa wzrostu gospodarki ${ }^{15}$. Rynek pracy relatywnie szybciej reagował na wzrost gospodarczy niż w okresach wcześniejszych. Należy przypuszczać, że obecnie minimalne tempo ożywienia PKB, któremu zacznie towarzyszyć wzrost liczby pracujących, będzie kształtować się na poziomie ok. 2\%. Jeżeliby przyjąć tę $2 \%$ granicę wzrostu bezzatrudnieniowego, to prognozy wzrostu gospodarczego w Polsce na lata 2016-2018 należałoby uznać za dość optymistyczne. Zarówno Międzynarodowy Fundusz Walutowy, Bank Światowy, Organizacja Współpracy Gospodarczej i Rozwoju, Komisja Europejska czy Ministerstwo Rozwoju w Polsce zakładają wzrost PKB w granicach 3,4\%-3,7\%.

\section{Bibliografia}

\section{Opracowania}

Aiginger Karl, Labour market reforms and economic growth - the European experience in the nineties, WIFO Working Papers 2004/232.

Barro Robert, Xavier Sala-i-Martin, Economic Growth, MIT Press, Cambridge 2004.

Bartosik Krzysztof, Popyt na prace w Polsce w warunkach spowolnienia gospodarczego, Studia Ekonomiczne 2011/3.

15 W przypadku szacunków opartych na danych za okres 2005-2014 granica wzrostu bezzatrudnieniowego była jeszcze niższa i wyniosła $1,8 \%$. 
Begg David, Fischer Stanley, Dornbusch Rudiger, Ekonomia, t. 2, PWE, Warszawa 1994.

Bolonek Ryszarda, Przyczyny i implikacje wzrostu bezzatrudnieniowego $w$ Polsce $w$ latach 1995-2005 w kontekście spójności społeczno-ekonomicznej, Nierówności Społeczne a Wzrost Gospodarczy 2008/12.

Góra Marek, Trwale wysokie bezrobocie w Polsce - wyjaśnienia i propozycje, Ekonomista $2005 / 1$.

Jarmołowicz Wacław, Kuźmar Sławomir, Bezzatrudnieniowy charakter wzrostu gospodarczego w Polsce i jej regionach (w latach 1995-2013), Współczesne Problemy Ekonomiczne, 2016/13.

Kotlorz Dorota, Przeobrażenia struktur zatrudnienia w Polsce w okresie transformacji-wybrane problemy, GWSH Katowice 2004.

Kotlorz Dorota, Zatrudnienie w procesie przemian polskiej gospodarki, AE, Katowice 1999.

Kryńska Elżbieta, Rynek pracy $w$ wybranych krajach. Metody przeciwdziatania bezrobociu, IPiSS, Warszawa 1999.

Kwiatkowski Eugeniusz, Kucharski Leszek, Tokarski Tomasz, Bezrobocie $i$ zatrudnienie a PKB w Polsce w latach 1993-2001, Ekonomista 2002/3.

Kwiatkowski Eugeniusz, Roszkowska Sylwia, Tokarski Tomasz, Granice wzrostu bezzatrudnieniowego w Europie i krajach WNP, Ekonomista 2004/1, s. 39-68.

Polska 2010 - raport o stanie gospodarki 2010, MG, Warszawa 2010.

Rocznik Statystyczny Województw (2006-2015), GUS, Warszawa 2016.

Timmer Marcel et al., Economic Growth in Europe. A Comparative Industry Perspective, Cambridge 2010 .

\section{Strony internetowe}

http://www.ue.katowice.pl/fileadmin/_migrated/content_uploads/08_Jadamus- Hacura_Melich-Iwanek_Bezzatrudnieniowy_wzrost.pdf; stan na 11.04.2016 r.

http://www.funduszestrukturalne.gov.pl/informator/npr2/ekspertyzy/stan $\% 20 \mathrm{i} \% 20$ perspektywy\%20kabaj.pdf; stan na 15.05.2016 r.

http://www.instytut.info/images/stories/ksiazki/01_ue_sl_gow/r04.pdf; stan na 15.05.2016 r.

http://www.rynekpracy.pl/artykul.php/wpis.566; stan na 20.04.2016 r.

http://stat.gov.pl/obszary-tematyczne/inne-opracowania/inne-opracowania-zbiorcze/polska-19892014,13,1.html; stan na 10.04.2016 r.

http://stat.gov.pl/wskazniki-makroekonomiczne; stan na 10.04.2016 r.

http://praca.interia.pl/news-wzrost-gospodarczy-a-rynek-pracy,nId,724048; stan na 11.04.2016 r.

Dorota KOTLORZ

Elżbieta SOJKA

\section{ECONOMIC GROWTH IN VIEW OF EMPLOYMENT POLAND IN YEARS 1995-2014}

\section{( S u m mary)}

Economic growth is one of the determinants shaping the labour market. Generally, there is no doubt that there is a positive relationship between these two categories, however the issue of quantitative relationships observed between them is more complicated. 
The paper attempts to analyse the relationship between GDP growth rates and the number of working people in Poland between 1995 and 2014, as well as to determine the nature of economic growth over the studied period. The paper also seeks to answer several research questions, i.e. What was the dynamics of GDP changes and the number of working people between 1995 and 2014 ? What was the employment absorption rate in different periods of Polish economy development and in selected economy sectors? What is the limit of jobless economic growth in Poland? Results of conducted research show that the labour market relatively slowly reacted to economic growth, and employment was increasing only when economic growth rate reached the level of about $4.5 \%$.

Keywords: economic growth; employment non-augmenting growth rate; labour force absorption factor; economic crisis 